tanum is pain in the suprapubic region. General praetitioners have for a long time recognized that pelvic inflammutory lesions in women produce a wide runge of referred pains, but there has not been a realization in the past that an even greater number of refered pains come from diseases in the male pelvis.

Dr. Walter Bherhing, Des Moines, Jowa: An instunce of rather unusual results following a local infective forus in the prostate rcently came to my attention. A truveling salesman sustained a rather simple injury, a blow on the thigh, after which the following seguence of changes ocenred: Ite developed a typical femoral phlebitis of the left leg, followe.l by a local abscess formation, which was incised and the exudate permitted to drain. Threc or four weeks of erenemal septicemia followed and then death. There was a rlaim for accident insurance because of the local injury. At the neropsy a deep-scated ubsess of the prostate, showing diplococei, was revenled. In addition, annther interesting fact which was brought out by Dr. MoCrae was a marked fibrosis of the myocardium, which also conld probubly be attributed to this latent prostatic infection. There had been a Neisserian infeetion five years before.

Dr. W. O. Buixues, Cmahu, Nob.: One effect of disturbince of the prostnte. which may be overlooked, has come unter my observation within the last three or four yenrs, with reference to serernl casice of abdominal tumor. dependent on obstruction of the prostate. The patient voided lis urine appurently to his own satisfaction, but the residual urine eventually caused a tumor, which finally beame distiuctiy palpathle. I dicl not use the catheter, on the promind that the patient was able to pass 8 ouness of urine. in my presence, without uny efrect on the tumor of the aldom 11 . Two or three days later, a catheter was passed and fline tumor entirely disnppeared. Whan a entheter is pussed into the prostate, in enses in which sufficient aceumulation in the bladder las oceurred to produce a good-sized tumor. it is surprising how muel urine can be withdrawn without having much effect on the bladifer. The reason is that for siveral weeks, or perhaps several montls, the tumor las resisted in such batek pressure of the urine in the kidneys thit the urine drained down in the bladtler about as fast as it was removed, 11 , to a certain point. This is probalbly (hwe raison for our failure in many of these cases. I reall one case in which the patient had a tumor for four monthe, and op:ra. tion was recommended. Jle finally went to the hospital, the dingnosis of prostatic obstruction was male and the entire tumor was removed by the use of the eatheter.

Dr. J. M. Anters, philadelphia: Dr. MeCrae has alled attention to certain couses of neurasthenic conditions that have been, to suy the lanst, neglected by genernl prictitioners in the past. Jle has well sad that a most careful history is an inportunt mutter in the study on these rases. 1 hiave learned from experience one fact to which 1 wish to all atlention, namely, that, in the absence of symptoms reforable to these organs and in the absence of the history of a gomiscocers infection, it will not do for the internist to exclulde disenses of the prostate and deep urethra as a cunse of merasthenic states. The sprecinlist knows that eithor arthritis or prostatitis may he ("elused by other organisms than the gonocnecus, for example, streptococcus pyogrnes. staphylococos pyogcose, anteus, albus nnd Bacillus coli commuris and others. The alssense of a history of specifie or gonomencens infection of the uretlu'n is not proof positive that losions do not exist which may eanse, th I know from exporienc.' rellex symptoms, particularly referred pains in the lark.

Plague Universally Endemic.--The discuse [plaguel is endemic on every continent in the world and in practically all countries, excepting, possibly, those of contincental fiurope. ln our own comtry any laxity of snnitary nurveillanee of the endemic centers on the pacific coast would result in the broudenst sprend of the disease. The same will ilpply to all endemic centers. It is a question of eternal vigilance.-R. $\mathrm{H}$. Greel, l'ub. Health Rep.

\section{SOME NERVOUS SYMPTOMS OF PERNICIOUS ANEMIA *}

\section{EUGENE RIGGS, A.M., M.D.} ST, PAUL, MINN.

About seventeen years ago my attention was especially attracted to the distinctiveness of the nervous syniptoms occurring in pernicious anemia, and at that time I reported a case before the Ameriean Neurological Assoriation in which the pathologic fiodings were those of a subarite combined degeneration of the spinal cord. At this time I called attention to the fact that the sclerosis wis apparently vascular, not sistemic in origin. Stencel has stated that this type of anemic patients give the higlest blood-count. Bramwell in 1910 reported a case in which the nervous symptoms were characteristionlly those of disseminated sclerosis and in which the aom symptoms developed three years before the anemia berame marked, and he emphasizes the fact that the melvous phenomenn may oceur a long time before the anemia or cachexin which precedes or acempanies the degrencrative changes in the spinal eord. This also has beren my ohservation. Not only is the blood-picture not lypical of that in pernicious ancmia, but the nervous symptoms newally precede for months or sometimes even veans the hlood-findings characteristic of this disense. In Bramwallis ase before mentioned the anemia was so slight that no blood examination was made and it atiracted attention and becume a feature of the case only a lew weeks before death.

fome years ago $I$ saw a patient in whom the clinical symdrome was that of a chucuic myelitis; the nervons manifestations overshaciowed by more than two years the lypionl blood-findings of perniejons anemia. Not inlicepunty the syliptoms resmble those of a transrerso myelitis or ol a multiple peripheral neuritis.

Acoriling to Stiumpell the nervous symptoms are similar to these of tabes; other writers compare them to ataxic maplegia. It is an interesting fact that the mervous syduche may be entirely wanting and yet there may be involvement of the spinal cord. Spiller has shown that the degenerative process may extend into the brain nxis.

'These symptoms may be purely subjective, such as numbmess in the arms and legs. (One of my patients (omplained that the bones were going througl the flesh. Arcording to Putnam paresthesius are strikingly roticuable. Knee-jerks may be normal, absent or watrgemited; ankle-clonus and the Babinski reflex may or may not be present; paraplegia may be vartial so thint the patient may move the legs freely in bel, or it may be complete. Associated usually with this is a loss of control over the bladder and fulum. Lightning pains and objective sensory disfurlances are common. Wilson recently reported a case in whichl gastric rrises were present. Dissociation, as in syringronyelia, lias been observed. Dimness of rision is quite frequent and occurs enrly. Optic neuritis, optic: atrophy, and hemorrhages associated with retinitis ale orcasionally reen. Mentality is as a rule umimpaired, alihought psychotic symptoms have been reported. Camp and ofleers have described cases in which the mental simptoms and signs of paresis were clenrly marked.

1)r. Addison, of suprarenal capsule fame, first described (and his description remains elassical until

* lergd in the Section on Norvous nnd Montul Diseases of the Amerisen Modical Associntfon, at the Sixty-Fourth Annual Session. Litd at Miuneupolis, June, 1013. 
to-day) a fatal and apparently causeless anemia which he designated idiopathic anemin, and it was while exploring pathologically the bodies of these patients to find the cause of this discase that le discovered the remarkable lesion which is basic in what we now know :s Addison's disease. Dr. Pepper tanght that this aflection is fundamentally a disease of the bone-marrow, the most important red-blood-making structure. On the other hand, Dr. William Hunter contended that pernicious ancmia was caused by an excessive destruction of the red blood-cells in the portal circulation, demandjug of the bone-marrow an extreme effort, and in these cisce, White tells us, the marrow js red like fetal marrow and is evidently in a state of great activity and "that in its lourry to cure the disease it is constantly pouring into the blood immature forms of red cells such as megaloblasts and normoblasts, poikilocytes and red rells staining badly, which give blood films so charas:teristic of pernicious anemia."

'The ultimate cause of pernicious anemia is most Iikely a toxin absorbed from the gastro-intestinal tract, but as to the exact nature of this toxin we nre entirely ignorant. 'This supposition affords us a plausible reason why in cortain cases the nervous symptoms precede by so long a period those of the blood-picture, the time incidence in either case depending on the point of initial attack he the toxin. Marie's suggestion as to the anatomic arrangement of the pial blood-ressels would account for the occurrence of the combined lesion. Its relatively poor blood-supply in health would probably make the dorsolateral cord particularly susceptible to degeneration in abnormal conditions ('Taylor). Certainly such an environment is favorable, and as to the selective altinty of toxins, who can say?

The following cases are a fair illustration of the nervous syndrome occurring in pernicious anemia:

Cass 1.-Miss K., aged 55, no nervous heredity, never robust but always well until fourteen years ago, when she hinl a nervous breakdown, was ill for two months. Two years ago she began to sufler from insomnia and loss of uppetite; whe complained at this time of a stuffed, bloated feding in the stomach. She was very nervous and despondent and has con. tinued so until the present time. Vertigo has been constant, worse in the morning; there has been continnous headnche, the pain extending from the nape of the neck over the head to the forehead. Her eyes feel "hs if they were pushed down." She complatins of pain in both heels and small of the lack, from which it extends to the front of the boly and down the anterior aspect to both extremities. There is a burning nensution in the heels as though they wore on fire and there is a constant shooting pain in the soles of both feet. Shortly nfter the legs and feet became affected she began to suffer puin in the hands; it extended up the arms, most severe loweren the hands and the ellows; it is intense and is of a barning, stinging character. Jiverything she tonches hurts "us if she were touching hot gluss." This pain is continuous. never lets up and seems to be steadily increasing. A yenr aud a latf ago slue first noticed that-her walking was unsteady and that when she attempted to wash her face she would nhmost fall over; whe says that her legs feel as if they were wooden and did not belong to her. There is a marked reak. ness in both lower extremities and she finds it very difficult to arise from her chair without the aid of her hands. There is Rombergism; knee-jerks and Achilles jerks lost; the plantur reflexes plus; superficial reflexes all present with the exception of the gluteal; tactile sense impaired from below the umbilicus. Cold normal, lieat exaggerated in the same area; urine normul. Hemoglobin 62 per cent, red blood-cells 4,061,000, white blood-cells, 4.112; color index .8; blood-pisture nen'mal, blood-pressure $130 \mathrm{~nm}$. Ifg.
Case 2.-Mrs. O., aged 01 ; father died of pneumonia in his sixty-ninth year, mother of senility in her eighty-sixth year; three brothers living and well, two dead, one of diphtheria, one of acute Bright's disease; three sisters living und well, two dead, one of tuberculosis, one of apoplexy. The pationt has had ten children of whom seven are living and well; one died of diphtheria, two died at birth. Climacterie at 48 . For the past twenty rears she has had a winter diarrhea. She began about five years ago to stumble in the dark. Althought the weight is normal, yet there has been " progresuve loss of strength; three years tho she noticed that she would tire very easily when walling up stairs; this eflort was accompanied by rupid heart action. She complained of "rocking" feeling in the head. She has had three sinking spolls lasting about a minute ench time, but did not lose conscionsness. . The lens have grown stendily weaker and there is marked atnxia. She has beon confined to bed since November, 1912. Jately she has had difficulty in starting the urine. There is a girdle sensa. tion around the ablomen and a numb foeling in the ligs to the hips and in the hands to the elbows. There is partial loss of tactile sense from the umbiliens downward. The loss of sensution in the upper extremities is more marked in the pulms of the hands. Patient has a yellow color but says she Jaws had this all of lier life. Her eyesight has been poor for the past fifter'n vears.

When examined Jannary, 1913, she was confined to hes bed, would lose leer legs in bed; there was marked Rombergism. knce-jerks normal, urine normal, hemoglobin 81 per cent., red blood-cells 3,584,000, white blood-eells 3,571 , color index 1.1 , no ancleated reds but poikilocytosis was marked.

CASE 3.-Mr. A., aged 53; father died of myocarditis in his fifty-seventh year, mother of apoplexy in her sixty-eighth year; a brother killed hinself; two sisters are living and well. The patient had diphtheria in his twenty-second year. He denies vencreal disoase. In 1900 he first noticed that fluid began to gather in the knees and wrists, nlso in the ankles (hydrops articuli); the accompanying pain was intense. In 1907 lie developed artinitis deformans. His face is a lemon color; this has been inerensing during the past eight months. Paresthesia in the hands and lower extremities. Impaired sensation (tactile) in both arms from ellows to finger-tips, and in the legs from the lower level of the buttocks down. Aside from Rombergism the neurologic examination was negr. ative. The hemoglobin was 36 per cent., red blood-cells 2,120,000, white blood-cells 5,130, color index 0.9); poikilocy. tovis, blool-pressure $180 \mathrm{~mm}$. Hg; urine, albumin with granular and hyaline casts. This is the second ase I have seen this year in which nephritis was associated with pernicious anemia.

CASE 4.-R., patient of Dr. llammes, aged 42, mother died of apoplexy in fifty-fifth year, futher of senility in his serenty-sixth year; five brothers living and well; "one died of (hronic nephritis; one sister living, but is asthmatic. The patient had acute articular rheumatiom in his fifteenth year. No history of venereal disease. Five children living and well. About three years ago he began to suffer from numbness and a burning sensation all over the body. For the past eight montlis he has gradually grown weaker, bedridden for three months. In the last three weeks memory has failed notably. At present there is pain associated with cramp in both legs. During the last year the patient has suffered from alternating attacks of diarriea and constipation. He can move his legs in bed with difficulty. There is marked ataxia, Babinski reflex in both feet and an impairment of all forms of sensation below the umbilicus. Hemoglobin, 46 per erent.; red blood-cells, 2.116,000); white blood-cells, 5,718; color index, 1.1; urine normal.

CAsE 5.-Mrs. H., aged 71; futher died of cardiac disease, mother of senility in her eightieth year; five brothers living and well; one died of diphtheria; one sister living in frail henlth, two sisters dead, one of apoplexy, one cause unknown. Two children living and well; two died at birth; there were two miscurriuges; one child died of diphtheria. Patient always well; elimacteric at 48 . Suffered from chronic constipation. In May, 1912, she first noticed difficulty in using hands. A cold sensation soon developed in all four extremities, also a 
tired feeling and loss of power. Psitient gradually grew worse and she complained of a distressing numb sensation in lieels and knees. There was at times tremor of right arm when trying to feed herself; also aching in the joints, especinlly of the wrists and in the bones of the forcarm. There was a rapi:l loss in strength and weight. Diarrhea without any appurent cause oceurred abont every ton days. profuse night sweats. The pain was so severe and so constant, with marke? tenderness over the nerve trunks, that she was supposed to be suffering from multiple neuritis and was sent to us for treatment of that disease. Deep and superficial reflexes normal, urine normal. Hemorlobin, 62 per cent.; red blood-cellis, $2.408,000$; white cells, 4,280; color index, 1.3 ; murked poikilocytosis; nucirated rods were present.

Because lenkopenia was present in all three eases it is well to recall 'T'irl's statement that in pernicions anemia you must have lenkopenia associated with the red blood-cell pisture. While there is grat reduction in both the red cells and the hemoglobin, this is proportionately much larger in the former, and hence eache (ell in order to compensate for their paucity has to carry an execss of hemoglobin. A higher color inilex therefore may be looked on as the constant of pernicions anemia and may be regarded as Nature's attempt it a curc (White).

The direct relation of the nervous syndrome to a diffuse primary non-systemic degeneration, oceurringr mostly in the spinal cord, has been definitely and " learly established. In my own ease, reported before the Amei ican Neurological Association in 1896, these changes were most noticeable in the middorsal region; from this point they steadily decreased, ceasing at the third lumbar segment. Commonly the nerve roots, peripheral nerves and the gray matter escape; yet a number of eases liave been reported in which the anterior horns were involved. The affertion of the blood-ressels is usually slight. This degeneration is, without doubt, due to a variety of toxic causes, namely, toxins from the gastrointestinal tract, poisons, metallic and vegetable (ergot of rye). Without doubt also this pathologic process may occur in persons with a deficient initial life-impulse in whom degenerative tendencies manifest themselves early. Aremia may precede, associnte itself with, or follow diffuse degencration of the spinal cord, but in many instances, notably the cases of Russell, Batten and Collier, there was nothing in the blood to suggest pernicious anemia. In pernicious anemia the anemia, like the cord changes, is a direct result of the toxin, be it a germ toxin or a chemical one, we do not know which. Probably in each instance the personal equation determines whether the pathologic process be a pernieious anemia with or without cord lesion, or a difluse degeneration of the spinal cord simply. 'The ultimate facts are that there is a nervous syndrome frequently found in pernicious anemia dependent on a diffuse, non-systemic, primary degeneration of the spinal cord, that this syndrome may antedate by months or even years the characteristic blood-pieture, and that both the anemia and spinal cord changes are the resultants of toxic influence. Contrasted with this must be the nervous phenomena incident to subacute, eombined degeneration of the spinal cord with which pernicious anemia is not associated.

Byrom Bramwell, in 1874, was struck with the fatty condition of the heart in pernicions ancmia, and as he had observer that arsenic was beneficial in eases of fatty henrt, he commenced its use in this disease. In 1910 he began the use of salvarsan and has since treated eleven cases with it. Of these four have been apparently cured (remission?), two were strikingly benefited, one case improved at first with ultimate relapse and deatl, and another patient became somewhat better, but died of pneumonia while under treatment; yet another patient is slightity improved, but still under his care at the time of writing (May 24, 1913), while two patients received no benefit whintever. He regards the intramuscular injection of salvarsan as the best method of administration because it will produce a sustained and continued effect, and he thinks its use in this form much superior to the ordinary ansenical treatment. Neosalvarsan gives much less pain and swelling, and is therefore to be preferred. He uses $0.3 \mathrm{gm}$. Life being so precarious in grave cases he considers it safer to give the smaller dose. My personal experience in the use of this dun in this disense has been somewhat limited. I prefer the intravenous method and the larger dose, 0.6 $\mathrm{gm}$. In Case 2 the pratient was greatly benefited under its nse; her nervous symptoms were rapidly disappearing when she left the hospital and she was getting so that she conld walk fairly well. Current medieal literature gives very conflicting reports regarding the benefit denived from this treatment; much further observation will be necessaly before we an properly estimate its true value.

\section{SE:3 Endicott Areade.}

\section{ABSTRACIT OF DISCUSSION}

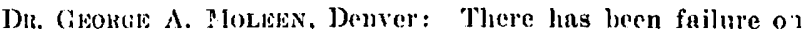
the part of most neurologists, I thiuk, to recognize the importance of blood chunges and their inlluence on nerve structure. The underlying systemic condition which lowers the resistanes of the nerve elements to nervous influenees las not beea siven sulliciont attention. We shall, I boljeve, realize th.t llis is particularly true when we. lecognize the incrensed irritability of the nervolis reflex centers and the irritability of nore structures romerally in high ultitules, where, if phisical factors are consilered, we must remember that the amount of hemoglobin, consequently the number of red blood-rells sent to the tissues generally, must necessarily be greater id view of the lessened atmospherie pressure. That nerve structures are vuluerable to influences under anemic states, when otherwise they would not be, has, I think, been genorally necepted. lior example, it is not uncommon to find that a fatigne nemrosia develops more rendily in an anemic person than in those persons who might be considered as presenting the untiporle of the unemic condition; in other words, in plethoric individuals. About two yeurs aro I saw a number of cases of neute combined degineration of the spinal cord. These cases have been comsidered as due to, or peculiarly asso. ciated with, blood-changes similar to those of pernicious anemia. I believe, however, the fact that they follow on nente infections diseases, has ben considered of nore importance in producing the anemia than that the nnemia is the cause of the dicense itself. Most of those cases have followed influeuzal infections.

Jr. Riggs hus emplnasized the importanee which he nttaches to the ancmic states as bringing about nervous diseases. and this is a factor whiels slould be given most enreful attention. It is un underlying systemic factor in rendering the nervous system of these persons more susceptible to organic elange under influences commonly recognized, than that of an individunl supplied with a normal hemoglobin content and a full corpuscular comt.

Dr. Jloweld 'T: Pensuina, Denver: I should like to spenk of a striking case that comes in one of the groups Dr. Rigess has becu discussing. 'lhe patient was an able attorney. When about 60 years of age he began to show his age with greai rapidity. He becume quite pale, his hair whitened rapidly, he lost a good doal of weight and the expression of his filca was considerably chunged. While working hard at a sum:ner 
session in Washington, he noticed especially fatigue in the legs. He could walk all right for a short distance, then rapidly became fatigued, but after \& rest could get along better. A few months later I hud the opportunity of examining him with bis family physician. At that time he was resting mentally and having some recreation; he wanted to play golf, but could not walk enough to do that with satisfaction. I could find no sign of organic disease, although he was examined with great care. In the winter he went to Honolulu and there he probably exercised too much. He had a stormy voyage coming back, and on arriving at San Fran. cisco showed some signs of myelitis. having lost control of his legs and slowing some sensory loss. He was at that time seen by Dr. Moffett of San Franciseo, and later when I saw him he had definite signs of transverse myelitis. There was motor loss and distinct sensory loss, with some disturbunce of the sphincters. He returned home and improved somewhat under rest in bed. The point that bothered both his physician and myself. however, was that while we thought this must be a case of pernicious anemia, and treated it accordingly, our examinations of the blood were, as we thought, quite inconclusive. 'There was only a moderate reduction in the reds, down to something over four million as I recollect, and the number of whites was about normal. The color index was slightly high, about 1.1 There were no normoblasts and there was no poikilocytosis. As time went on there was a continued slow reduction in the red cells, but not enough to account for his symptoms, so far as we could determine. Then an obstucle to further study occurre?. The patient's daughter had died of pernocions anemia, and he had read much on the subject and studied his daughter's case with the utmost care. He was sensitive and begged to be relieved of the frequent tests of the blood. He had a horror of everything associated with anemia, even of the simple prick of the finger, and we had to respect his wishes. Toward the last week or two of his life the anemic appearance was striking. I think it was one of those cases spoken of by Dr. Riggs, without great changes in the blood. The changes in the cord were elinically distinct. It was the ordinary typa of transverse myclitis, coming on with a sharp exacerbation at the time of the Honolulu visit, afterward showing slight changes and a gradual loss.

\section{TAL SERODIAGNOSIS OF PREGNANCY *}

\section{HENRY SCHWARZ, M.D. sT. LOU1S}

In speaking of methods for serodiagnosis of pregnancy, I refer to the biologic tests of Abderhalden only, because the method of Rosenthal, while of considerable scientific interest, appears to be of small practical value. It is applicable during advanced pregnancy only, and all conditions associated with increased destruction of the body proteins respond to the same test.

Abderhalden's methods of serodiagnosis of pregnancy, on the other hand, give reliable information just as soon as the ovum is permanently implanted; these methods are based on specific reactions and they are suited for the widest application in the study of physiologic and pathologic conditions.

To appreciate the value and the scope of these metliods it is essential to have a clear understanding of the underlying principles and to be familiar with the monumental work of Abderhalden on cell metabolism and on protective ferments, which covers a period of more than ten years of intense activity.

It appears that each body-cell, including the white and the red corpuscles and the blood-disks, carries on its own

* Read in the Section on Obstetries, Gynecology and Abdominal Surgery of the Amerlenn Medical Assoclation, at the Sixty-Fourth Annual Session, beld at Milnneapolls, June, 1013. metabolism; it takes up nutritive substances from the blood, digests them with the aid of various enzymes, using the end-products of the intracellular digestion for the development of energy or linking them together into complex building-stones for the development or the repai: of its own body.

The protoplasm of one group of eells differs from that of other groups of cells chemically and physically; difference of function implies difference in structure. The protoplasm of renal epithelial cells differs in structure from the protoplasm of inuscular fibers; glands with internal secretion, sending out substances which act on special cells in distant parts of the body, require special structure both in the cells whicil send out these sulbstances and in the cells on which they act.

Such intercommunicaton of two or more sets of cells is made possible by the fact that the intervening medium, the blood, is, under normal conditions, of pretty constint composition, and that the physical and chemical conditions in the various cell-groups likewise remain fairly even.

Nutritive substances pass into the blood from two sources: namely, from the gastro-intestinal tract and from the body-cells; before entering the blood-stream they nust be divested of all individual character and be reduced to the simple cleavage products which form normal constituents of the blood.

For the purpose of this paper I shall limit this review to protein metabolism.

Protein foodstuff's, no matter what their source, are conglomerations of amino-acids; these are joined together into small groups like the blocks in a Chinese puzzle; the amino group of the one acid is always joined to the carboxyl group of the other; these small groups are joined together to larger and still larger groups, until they form the large albumin-molecule.

So firmly are these amino-acids joined together, that nothing short of repeated blasting will separate the albumin molecule into its original building-stones; this blasting is accomplished by the ferments of the gastro-intestinal canal with the aid of water, which enters at the points of juncture, that is, by hydrolysis.

'The work of reducing the albumin molecule to aminoacids is a gradual one; the pepsin of the stomach in the presence of hydrochloric acid breaks it up into large fragments, proteoses and peptones; the trypsin of the pancreas, activated on entering the intestines, reduces these large fragments into smaller ones, the peptides and anino-acids; the enzyme found in the cells of the intestinal mucosa, the erepsin, completes the reduction into amino-acids.

Substances which are absorbed from the intestinal canal must pass through the liver before they can get into the general circulation. Here they are once more closely inspected by the liver-cells and, if anything has passed that is in the least degree foreign to the blood, it is held back and reduced to a blood-own substance. The liver likewise prevents a flooding of the system with blood-own substances by holding back an excess of such substances and letting them pass on in small quantities only, or by converting them to forms which can be stored up in the body for finture use.

The other source from which nutritive substances and products of metabolism enter the blood-current is from the cells of the body.

All cell protoplasm is foreign to the blood; it has been built up by the cells from the amino-acids. which are biood-own and it must be reduced to its original components before it can be allowed to enter the blood. 